\title{
PENINGKATAN PERAN RUMAH BELAJAR GARASI DALAM MENJAGA SEMANGAT BELAJAR ANAK-ANAK DI MASA PANDEMI
}

\author{
Agus Riyanto ${ }^{1 *}$, Junaidi ${ }^{1}$, Iqbal Firdaus ${ }^{1}$, Simon Sembiring ${ }^{1}$ \\ ${ }^{1}$ Universitas Lampung, Bandarlampung, Indonesia \\ *agus.riyanto@fmipa.unila.ac.id
}

\begin{abstract}
Abstrak: Pandemi Covid-19 yang melanda seluruh dunia mempengaruhi proses pembelajaran anak sekolah, khususnya di Indonesia. Mereka diharuskan belajar dari rumah secara daring sehingga memerlukan pendampingan dari orang tua. Orang tua dari anak-anak dengan berbagai latar belakang pendidikannya belum optimal dalam melakukan pendampingan belajar ini. Program pengabdian kepada masyarakat ini bertujuan untuk meningkatkan peran Rumah Belajar Garasi dalam menjaga semangat belajar anak-anak di lingkungan RT 04 Jalan Kramat Jaya, Desa Hajimena, Natar, Lampung Selatan. Untuk mencapai tujuan tersebut, tim pengabdian bersama pengelola rumah belajar membuat perangkat media pembelajaran berupa modul dan video yang disebut dengan Garasi kids serta pemberian edukasi kepada warga selaku orang tua. Tim pengabdian juga membuat program pendukung lainnya seperti kegiatan mewarnai dan membuat mozaik untuk anak serta menghadirkan mobil pintar di Rumah Belajar Garasi. Pelaksanaan kegiatan pengabdian ini dilakukan melalui dua pendekatan yaitu edukasi terhadap orang tua dan pendampingan anak mereka dalam proses belajar. Edukasi kepada orang tua ditujukan agar mereka memiliki kemampuan untuk membimbing anak-anaknya saat belajar di rumah. Sementara pendampingan kepada anak ditujukan agar mereka lebih mudah untuk memahami materi pelajaran khususnya bernalar matematika. Hasil pengabdian menunjukkan bahwa penggunaan Garasi kids pada Rumah Belajar Garasi yang disertai keaktifan, semangat belajar, anak dan juga dukungan orang tua mampu meningkatkan kemampuan bernalar matematika anak-anak secara signifikan. Meskipun terdapat sebagian kecil anak-anak berada pada predikat cukup baik dalam menyerap matematika, namun mereka memiliki keunggulan di bidang seni dan kemampuan bekerja sama dengan teman-temannya. Minat baca anak-anak juga tumbuh dengan kehadiran mobil pintar di Rumah Belajar Garasi. Dengan demikian, optimalisasi Rumah Belajar Garasi melalui Garasi kids dapat memberikan kontribusi positif terhadap proses pembelajaran anak di rumah pada masa pendemi.
\end{abstract}

Kata Kunci: anak-anak, Rumah Belajar Garasi, Garasi kids, pandemi Covid-19

\begin{abstract}
The Covid-19 pandemic has hit the world affecting the learning process of school children, especially in Indonesia. They are required to study from home so they need assistance from their parents. Parents with various educational backgrounds are not optimal in providing this learning assistance. This community service program aims to increase the role of the Rumah Belajar Garasi in maintaining the enthusiasm of children's learning in RT 04 Kramat Jaya Street, Hajimena, Natar, South Lampung. To achieve this goal, we created Garasi kids and educated the society. In addition, other supporting programs were also made, such as coloring, making mosaics, and presenting Mobil Pintar. The implementation of this program was carried out through two approaches, namely educating parents and assisting children in learning. Education for parents is intended to guide their children while studying at home, while mentoring children is targeted to make it easier for them to understand the subject matter. The results of this program show that the use of Garasi kids in Rumah Belajar Garasi accompanied by activeness, enthusiasm for children's learning and also parental support can significantly improve children's mathematical reasoning abilities. Although a small number of children are in a pretty good predicate in understanding mathematics, they have the ability in the arts and work together with their friends. Children's interest in reading also grows with the coming of mobil pintar to the Rumah Belajar Garasi. Thus, the optimization of the Rumah Belajar Garasi through the Garasi Kids makes a positive contribution to the children's learning process at home during the pandemic.
\end{abstract}

Keywords: children, Rumah Belajar Garasi, Garasi kids, pandemic Covid-19 


\section{Pendahuluan}

Desa Hajimena ialah salah satu desa yang terletak di Kecamatan Natar, Kabupaten Lampung Selatan. Desa ini berbatasan langsung dengan Kota Bandarlampung dan Kabupaten Pesawaran. Salah satu wilayah dari desa ini ialah lingkungan Rukun Tetangga (RT) 04 yang terletak di Jalan Kramat Jaya Dusun II. Meskipun posisinya sangat dekat dengan kota, namun lingkungan ini mulai ramai dihuni oleh warga sekitar awal tahun 2016. Sekarang telah didirikan ratusan rumah yang tersebar di atas tanah kaplingan dan tiga blok komplek perumahan di lingkungan RT ini. Sebagian besar warga bekerja menjadi pengrajin, satpam, batu bata, petani, buruh, dan pedagang. Sebagian lainnya menjadi karyawan di perusahaan, ASN, dan TNI/Polri. Pada umumnya, mereka memiliki anak yang masih menempuh pendidikan di tingkat sekolah dasar (SD). Menurut pendataan yang dilakukan oleh tim pengabdian terdapat puluhan anak SD di RT tersebut. Mereka mejalani pendidikan di SD negeri atau swasta di Desa Hajimena, serta SD yang terletak di Kota Bandarlampung dan Kabupaten Pesawaran.

Aktivitas belajar semula berjalan normal, anak-anak menjalani kegiatan belajar di sekolah masing-masing dengan bimbingan guru secara langsung. Namun, keadaan menjadi berubah ketika terjadi pandemi Covid-19. Mereka harus belajar dengan pendampingan dari orang tuanya di rumah mereka masing-masing. Kegiatan belajar dilakukan secara daring (online) menggunakan telepon pintar (smart phone). Namun, ada sekolah yang menempuh metode yang berbeda dalam menjalankan kegiatan pembelajaran. Guru memberikan materi dan tugas yang harus diambil oleh siswa dan orang tuanya di sekolah, kemudian tugas tersebut harus dikerjakan oleh siswa dengan didampingi orang tuanya. Selanjutnya, tugas tersebut dikumpul kembali kepada gurunya di sekolah pada jadwal yang sudah ditentukan. Perubahan metode belajar ini, memaksa orang tua harus sigap dan berusaha untuk memainkan peran seperti guru di sekolah. Namun, mereka mengalami kesulitan untuk mendampingi dan mengarahkan anaknya saat belajar di rumah karena terkendala dengan latar belakang pendidikan formal mereka yang terbatas. Menurut penelitian, orang tua mengalami kesulitan untuk mendapingi anaknya saat belajar di rumah disebabkan karena beberapa faktor, yaitu: (1) tidak menguasai materi pelajaran dengan baik, (2) tidak memiliki kecakapan untuk menumbuhkan minat belajar anaknya, (3) sibuk bekerja, (4) kurang sabar, (5) tidak terampil mengoperasikan telepon pintar, dan (6) adanya gangguan jaringan internet (Anugrahana, 2020; Mustara \& Santaria, 2020; Wardani \& Ayriza, 2021). Berbagai kendala tersebut sebagian besar diderita oleh orang tua dari anak-anak SD di lingkungan RT 04.

Belajar di rumah dalam waktu yang lama menyebabkan timbulnya kejenuhan bagi anakanak maupun orang tuanya. Orang tua tidak jarang mengeluh karena tidak bisa mengajari anaknya secara optimal karena ketidaktahuannya. Menghadirkan guru privat ke rumah sebenarnya bisa menjadi salah satu alternatif solusi, namun hal ini sulit dilakukan karena sebagian besar dari mereka memiliki penghasilan yang terbatas. Akhirnya, kegiatan belajar berjalan tidak maksimal dan tidak sesuai dengan yang diharapkan oleh pihak sekolah. Permasalahan ini membawa dampak buruk bagi anak-anak, misalnya: mereka tidak menerima 
materi pelajaran secara tuntas, dan tidak berkembangnya kemapuan akademik maupun nonakademiknya. Selain itu, anak-anak menjadi jenuh sehingga hanya bermain-main dengan telepon pintarnya (Sari, Tusyantari, \& Suswandari, 2021).

Permasalahan sekolah daring yang dirasakan warga RT 04 ini mendorong didirikannya tempat belajar oleh beberapa orang warga. Tempat belajar itu diberi nama Rumah Belajar Garasi. Kata garasi menunjukkan tempat kegiatan yaitu garasi rumah dan juga menunjukkan akronim dari "gerbang belajar dan inspirasi". Memberi pendampingan untuk anak-anak yang ingin belajar secara gratis ialah misi utama didirikannya tempat belajar tersebut. Pengelola membagi anak-anak menjadi beberapa kelompok kecil agar kegiatan belajar terkontrol dan relatif aman dari sisi kesehatan. Hari Sabtu dan Minggu dipilih sebagai hari pelaksanaan kegiatan belajar. Anak-anak diberikan bimbingan untuk belajar bernalar matematika karena sebagian besar anak-anak tidak menguasai pelajaran tersebut dengan baik. Padahal, mata pelajaran ini dipandang sangat penting untuk dikuasai oleh anak-anak kerena menjadi pondasi dasar sejumlah pelajaran lainnya (Siregar, 2017).

Kegiatan pendampingan belajar di Rumah Belajar Garasi sudah dirasakan manfaatnya oleh orang tua dan anak-anak di lingkungan RT 04 Jalan Kramat Jaya Hajimena, meskipun waktu belajar, media pembelajaran, dan jumlah pendampingnya sangat terbatas. Oleh sebab itu, tim pengabdian dari Universitas Lampung berkerja sama dengan pengelola Rumah Belajar Garasi membuat media pembelajaran (Garasi kids) untuk meningkatkan pelayanan bagi anakanak. Garasi kids ialah media pembelajaran bernalar matematika yang terdiri dari video (audio visual) dan modul pembelajaran (visual). Menurut studi, penggunaan media audio visual mendukung ketercapaian tujuan pembelajaran karena media ini dapat digunakan melatih peserta didik untuk menyerap materi pelajaran melalui pandangan dan pendengarannya hingga mereka mampu memperoleh pengetahuan, keterampilan, maupun sikap ilmiah (Hayati, Harianto, \& Harianto, 2017; Jatmika, 2005). Sementara itu, media visual mengupayakan agar perserta didik mengoptimalkan pandangannya dalam belajar. Kendatipun demikian, jika media ini dibuat menarik dan terkonsep maka juga dapat membantu tercapainya ketuntasan belajar (Rosidah, 2016). Tujuan diadakan kegiatan pengabdian ini adalah meningkatkan peran Rumah Belajar Garasi untuk menjaga semangat belajar anakanak di lingkungan RT 04 Jalan Kramat Jaya Hajimena selama masa pandemi.

\section{Metode}

Menurut beberapa studi, kegiatan belajar secara daring yang dilaksanakan selama pandemi ini berjalan kurang optimal, karena mayoritas orang tua tidak dapat mengajari anakanaknya untuk memahami materi pelajaran di sekolah. Terbatasnya interaksi guru dan siswa dalam menjelaskan materi juga menjadi salah satu faktor kendala. Kegiatan pendampingan dalam kelompok kecil dalam satu lingkungan tempat tinggal untuk menumbuhkan motivasi dan kemandirian belajar siswa, serta pembinaan orang tua siswa di saat masa pandemi cukup efektif untuk meminimalisir berbagai masalah dalam mencapai tujuan akhir pembelajaran (Cahyati \& Kusumah, 2020; Handayani et al., 2020; Lestari, Purnamasari, \& Purnamasari, 
2021; Yuhenita, Muliyani, Alfahmi, \& Abdillah, 2021). Kegiatan ini dinilai cukup efektif karena dilakukan pendekatan dari dua sisi, yaitu dari sisi siswa dan orang tuanya. Orang tua dapat membantu anak-anaknya untuk belajar dan anak-anaknya memiliki cukup bekal untuk memahami materi pelajaran, sehingga keduanya dapat saling bekerja sama.

Untuk mengatasi permasalahan pembelajaran daring yang dihadapi oleh warga (anakanak dan orang tuanya) di wilayah Jalan Kramat Jaya RT 04 Desa Hajimena Kecamatan Natar, tim pengabdian bersama pengelola Rumah Belajar Garasi menerapkan pendekatan dengan cara mengeduksi orang tua dan melakukan pendampingan kepada anak-anaknya sebagaimana telah dilakukan oleh beberapa studi sebelumnya karena cara ini dipandang efektif dalam mencapai tujuan pembelajaran. Metode yang digunakan dalam pelaksanaan kegiatan pengabdian kepada masyarakat ini adalah metode ceramah dan diskusi untuk mengedukasi orang tua siswa. Sedangkan untuk pendampingan anak-anak dilakukan dengan menerapkan metode ceramah, diskusi, dan eksperimen.

Kegiatan pengabdian ini dibagi menjadi empat tahap kegiatan, yaitu: pembuatan Garasi kids, sosialisasi (edukasi) untuk orang tua, pendampingan belajar, dan evaluasi kegiatan.

1. Pembuatan Garasi kids

Pada tahap ini, tim pengabdian bersama dengan pengelola Rumah Belajar Garasi membuat Garasi kids yang berisi seperangkat media pembelajaran berupa modul dan video untuk mendampingi anak-anak saat belajar. Kontennya berisi materi pembelajaran matematika yang diajarkan di sekolah, namun dibuat menjadi lebih sederhana agar anakanak lebih mudah memahaminya.

2. Sosialisasi (edukasi) untuk orang tua

Pada tahap ini, tim pengabdian dan pengelola Rumah Belajar Garasi mengeksplorasi berbagai permasalahan yang dihadapi orang tua, memotivasi, dan memberikan tips sederhana untuk mendampingi anaknya saat belajar di rumah. Pada kegiatan ini, kami juga membagikan Garasi kids dan menjelaskan konten di dalamnya agar mereka dapat membantu anaknya saat belajar di rumah.

3. Pendampingan belajar

Kegiatan pendampingan dilaksanakan pada setiap hari Sabtu dan Minggu pagi selama beberapa bulan. Anak-anak dibagi menjadi kelompok kecil berdasarkan kelas di sekolah. Mereka diajari konsep dasar matematika serta diberikan tips sederhana menyelesaikan kasus matematika. Kemudian, mereka diminta untuk berlatih mengerjakan soal untuk menumbuhkan keterampilan bernalar. Materi yang diajarkan mencakup konsep dasar dan pengayaan matematika, seperti: (a) penalaran tentang bilangan, penjumlahan, dan pengurangan, (b) penalaran tentang perkalian, pembagian, pecahan, dan pemfaktoran, (c) pengenalan bangun datar, (d) pengukuran waktu, panjang, dan berat, (e) menghitung debit, dan (f) mengenal sistem koordinat kartesius. Pada kegiatan pengabdian ini, anakanak juga dibimbing untuk bereksperimen membuat karya seni dan berlatih membaca buku. Kegiatan ini ditujukan untuk mengamati beberapa bakat mereka di luar kemampuan akademiknya. Hasilnya disampaikan kepada orang tua agar mereka mengetahui bakat non-akademik anaknya. 
4. Evaluasi kegiatan

Untuk mengevaluasi tingkat penalaran anak-anak terhadap matematika maka mereka diberi soal tes yang terdiri dari soal multiple choice dan uraian singkat. Kegiatan ini dilaksanakan dua kali dan dibingkai dalam bentuk perlombaan untuk menambah semangat anak-anak. Tingkat penalaran mereka dievaluasi dengan cara membandingkan nilai tes terhadap kriteria penyerapan materi yang telah dibuat oleh tim pengabdian. Efektivitas kegiatan pendampingan dianalisis berdasarkan nilai rata-rata hasil tes. Sedangkan, karya seni dan minat baca anak-anak dievalusi dengan cara mengamati hasil karya yang mereka buat dan melihat keaktifan mereka dalam membaca buku.

\section{Hasil dan Pembahasan}

Tim pengabdian bersama pengelola Rumah Belajar Garasi memulai kegiatan pengabdian dari membuat Garasi kids yang terdiri dari modul dan video pembelajaran. Modul yang dibuat berisikan materi dasar matematika yang diajarkan di sekolah seperti ditunjukkan pada Tabel 1. Modul ini diharapkan dapat dimanfaatkan oleh anak-anak untuk mempelajari matematika dengan cara yang mudah karena materinya dibuat sederhana. Modul ini digunakan untuk memandu anak-anak saat belajar di Rumah Belajar Garasi. Namun, mereka juga dapat mempelajarinya secara mandiri di rumah masing-masing. Modul tersebut dibuat full color seperti ditunjukkan pada Gambar 2. Hal ini dilandasi oleh alasan bahwa perpaduan warna yang menarik yang dituangkan dalam modul pembelajaran dapat menumbuhkan perhatian dan motivasi belajar anak-anak, serta dapat menumbukan perasaan suka dan kemauan mereka untuk belajar (Purnama, 2010). Selanjutnya, kami membuat video yang berisikan penjelasan dari materi di dalam modul. Video ini dibuat agar anak-anak lebih cepat memahami materi karena bisa ditonton berulang kali. Salah satu contoh dari video yang telah dibuat ialah video tentang pengantar penjumlahan seperti ditunjukkan pada Gambar 1.

Tabel 1. Konten materi dalam Garasi kids

\begin{tabular}{cl}
\hline Bagian & \multicolumn{1}{c}{ Cakupan materi } \\
\hline 1 & Penalaran tentang bilangan, penjumlahan, dan pengurangan \\
2 & Penalaran tentang perkalian, pembagian, pecahan, dan pemfaktoran \\
3 & Pengenalan bangun datar \\
4 & Pengukuran waktu, panjang, dan berat \\
5 & Menghitung debit \\
6 & Mengenal sistem koordinat kartesius \\
\hline
\end{tabular}

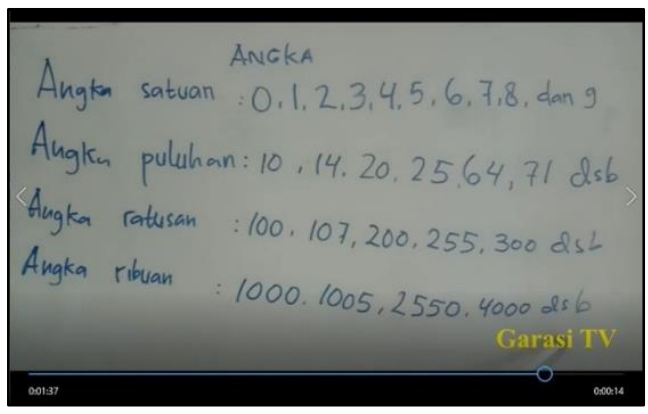

Gambar 1. Screenshot video materi pengantar penjumlahan 


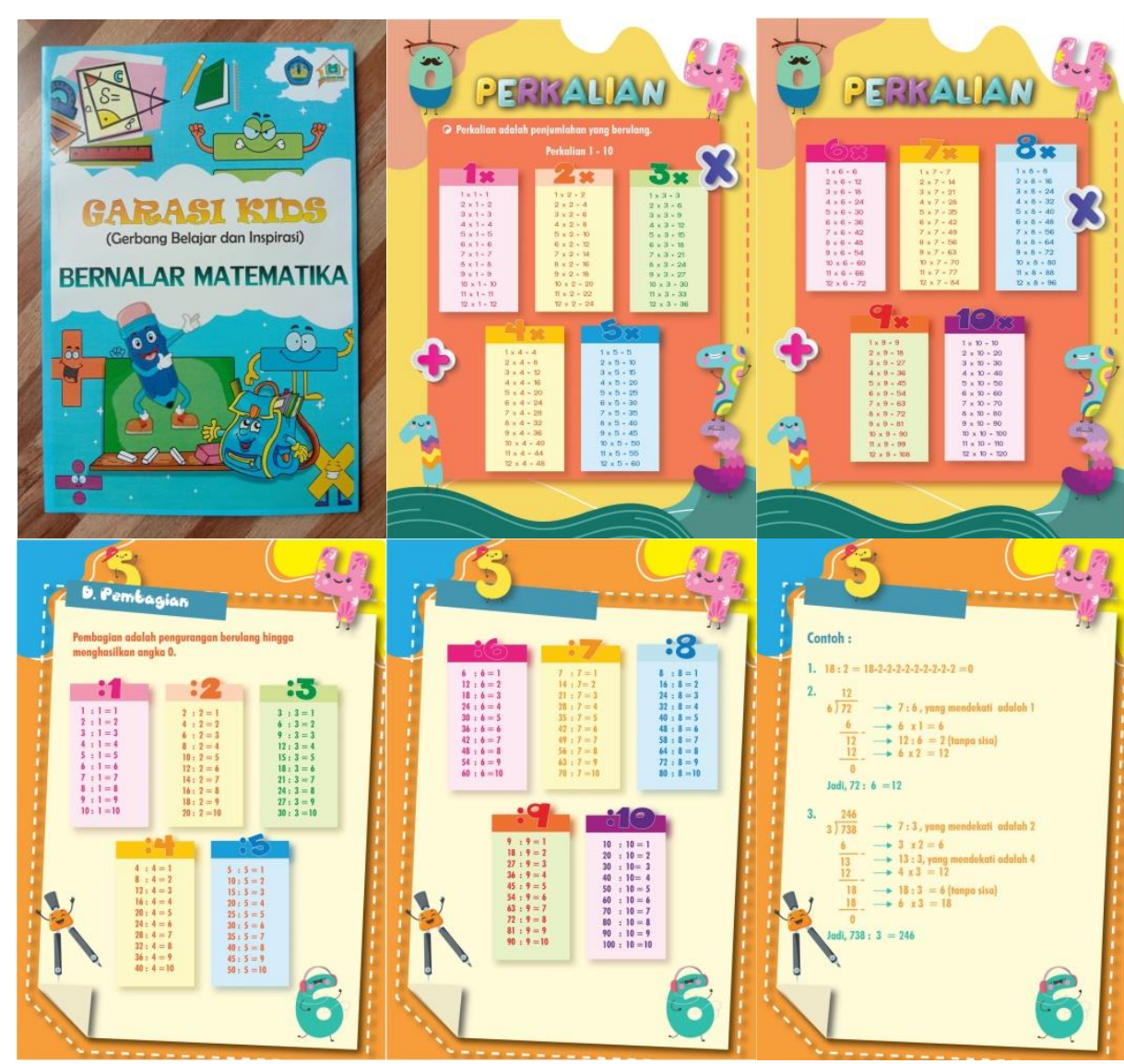

Gambar 2. Halaman sampul dan beberapa contoh materi di dalam modul Garasi kids

Agenda pengabdian selanjutnya adalah sosialisasi kepada orang tua yang ditujukan untuk menggali problematika mereka selama sekolah daring diterapkan. Kegiatan ini diikuti oleh 33 peserta dan dihadiri oleh ketua RT setempat seperti pada Gambar 3. Melalui diskusi interaktif, tim pengabdian mengetahui beberapa problematika yang dihadapi orang tua selama kegiatan belajar daring. Beberapa problematika utama yang dihadapi orang tua, antara lain: (1) keterbatasan latar belakang pendidikan menyebabkan mereka sulit untuk mengajari anaknya, (2) meningkatnya kebutuhan belanja kuota internet karena harus berinteraksi dengan guru di sekolah dan untuk kebutuhan mencari penyelesaian dari tugas-tugas anaknya di internet, dan (3) merasa bahwa anaknya tidak bisa mengikuti kegiatan belajar daring dengan baik.

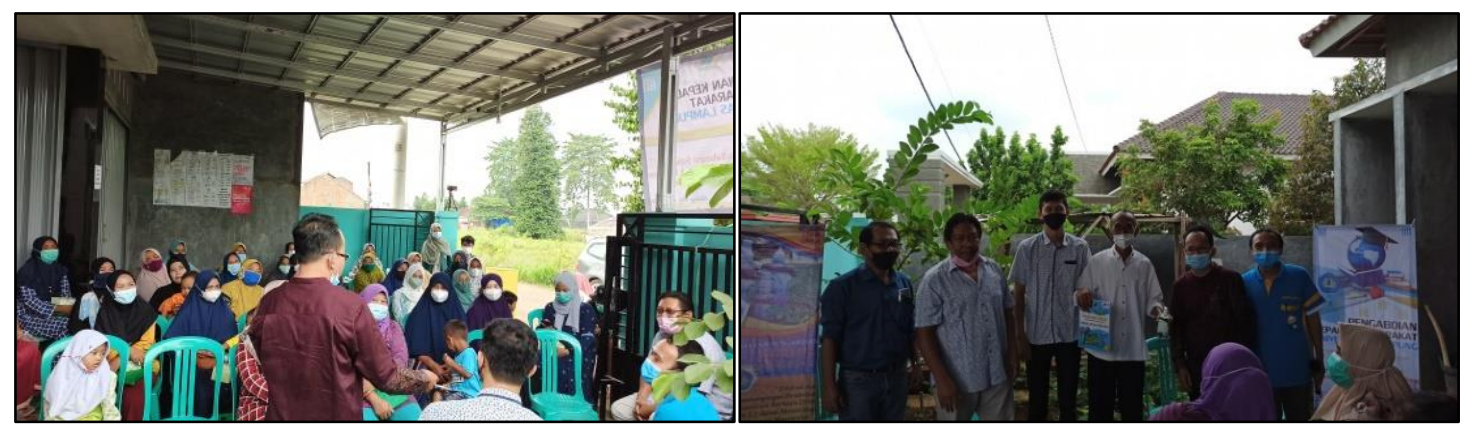

Gambar 3. Kegiatan sosialisasi kepada orang tua warga dan penyerahan Garasi kids secara simbolik kepada ketua RT setempat 
Berdasarkan problematika yang dihadapi oleh orang tua, tim pengabdian memberikan berbagai tips agar mereka dapat mendampingi anaknya saat belajar di rumah. Beberapa tips yang diberikan kepada mereka, antara lain: (1) tips bersabar saat mendampingi anaknya saat belajar di rumah, (2) tips meningkatkan keterampilan diri, (3) tips menumbuhkan daya nalar anak, dan (4) tips memotivasi anak agar mereka semangat untuk belajar. Dalam kegiatan sosialisasi ini, Garasi kids juga dibagikan kepada mereka yang selanjutnya dapat dimanfaatkan oleh anak-anaknya. Tim pengabdian juga menjelaskan secara detil mengenai konten yang dimuat di dalamnya dan cara memahami konten tersebut sehingga mereka bisa membantu anaknya saat belajar di rumah.

Tabel 2. Kelompok dan materi yang telah dipelajari selama kegiatan pendampingan

\begin{tabular}{ccll}
\hline Kelompok & Kelas & & \multicolumn{1}{c}{ Materi } \\
\hline 1 & II SD & 1. Penjumlahan bilangan satuan, puluhan, dan ratusan \\
& & 2. Pengurangan bilangan satuan, puluhan, dan ratusan \\
& III SD & 1. Penjumlahan bilangan puluhan, ratusan, dan ribuan \\
& & 2. Perkalian $(1-5)$ \\
3 & IV SD dan & 1. Penerapan Permasalah perkalian puluhan \\
& V SD & 2. Penerapan permasalah pekalian puluhan dan ratusan \\
& 3. Pembagian & 4. Pecahan (penjumlahan, pengurangan, dan \\
& & 5. Penyederhanaan pecahan)
\end{tabular}

Tahap selanjutnya dari kegiatan pengabdian ini ialah pendampingan belajar untuk anakanak yang dilaksanakan pada setiap akhir pekan oleh tim pengabdian beserta pengelola Rumah Belajar Garasi. Perserta kegiatan ini berjumlah 19 anak SD yang dibagi menjadi 3 kelompok. Setiap kelompok di dampingi oleh satu pendamping dan mereka diajari materi bernalar matematika sesuai dengan materi yang dimuat di dalam Garasi kids. Materi yang telah berhasil diajarkan kepada anak-anak selama kegiatan pengabdian ini ditunjukkan pada Tabel 2. Dalam kegiatan pendampingan ini, anak-anak dilatih daya serapnya terhadap materi dan diasah kemampuannya. Mereka diminta mengerjakan soal-soal secara bergiliran untuk menumbuhkan keberanian dan kepercayaan dirinya. Aktivitas pendampingan anak-anak ditunjukkan pada Gambar 4.

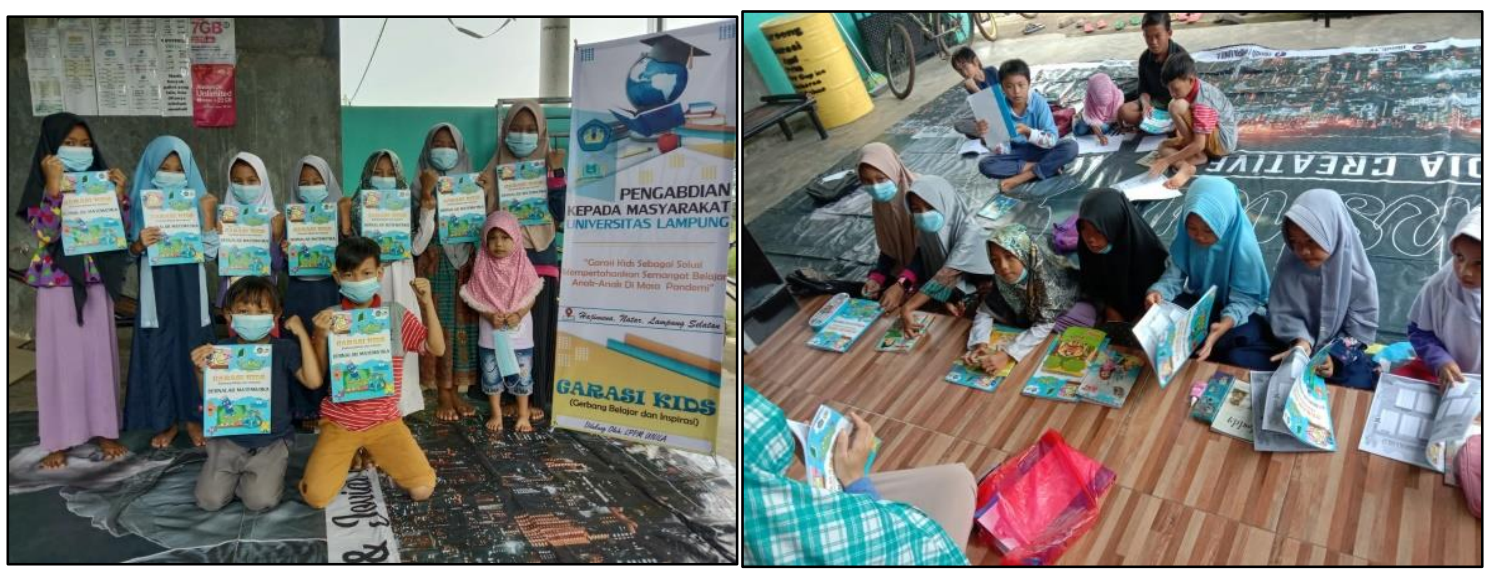

Gambar 4. Kegiatan pendampingan belajar di Rumah Belajar Garasi 
Daya serap anak-anak terhadap materi yang telah diajarkan dievaluasi melalui kompetisi berhadiah untuk menjaga dan meningkatkan semangat anak-anak untuk terus belajar. Selama kegiatan pengabdian telah dilakukan evaluasi sebanyak 2 kali. Evaluasi pertama ditujukan untuk mengukur daya serap anak-anak terhadap materi 1 bagi kelompok 1, mengukur daya serap anak-anak terhadap materi 1 bagi kelompok 2, dan mengukur daya serap anak-anak terhadap materi 1, 2, dan 3 untuk kelompok 3, seperti yang ditunjukkan pada Tabel 2. Evaluasi tahap ke dua ditujukkan untuk mengukur daya serap anak-anak terhadap materi yang lainnya seperti yang dimuat pada Tabel 2. Anak-anak diminta menyelesaikan soal multiple choice dan uraian singkat dengan jumlah masing-masing ialah 20 dan 10 butir. Untuk mengukur daya serap mereka terhadap materi yang telah diajarkan, tim pengabdian membuat kriteria penilaian dengan skala seperti ditunjukkan pada Tabel 3.

Tabel 3. Kriteria nilai dan predikat daya serap anak terhadap materi

\begin{tabular}{ccc}
\hline No & Nilai & Predikat daya serap terhadap materi \\
\hline 1 & $\geq 80$ & Sangat baik (SB) \\
2 & $71-79$ & Baik (B) \\
3 & $61-70$ & Cukup baik (CB) \\
4 & $51-60$ & Kurang (K) \\
5 & $50 \leq$ & Sangat kurang (SK) \\
\hline
\end{tabular}

Nilai dan predikat daya serap anak-anak terhadap materi pelajaran berdasarkan kegiatan evaluasi pertama ditunjukkan pada Tabel 4. Hasil evaluasi pertama ini mengungkap bahwa terdapat 21,05\% anak (4 orang) memiliki predikat kurang, 31,58 \% anak (6 orang) memiliki predikat cukup baik, dan $47,37 \%$ anak (9 orang) memiliki predikat baik dalam menyerap materi pelajaran. Dari evaluasi pertama ini diketahui bahwa jumlah anak memiliki predikat kurang dan cukup baik mencapai 52,63 \%. Tingginya presentase anak pada predikat ini karena sebagian anak-anak kelompok 1 belum mahir untuk membedakan angka satuan, puluhan, dan ratusan, sedangkan sebagian besar anak-anak kelompok 2 dan 3 tidak hafal perkalian. Padahal kedua materi ini sangat penting bagi mereka untuk mempelajari materi selanjutnya. Menyikapi kondisi ini, anak-anak terus dilatih untuk membedakan angka jenisjenis angka, dan dilatih untuk menghafal perkalian dengan menerapkan trik sederhana yang telah diajarkan kepada mereka. Mareka terus diberi pendampingan sehingga dari waktu ke waktu semakin menunjukkan peningkatan sebagaimana ditunjukkan oleh hasil tes evaluasi kedua. Hasil tes kedua ini mengungkap bahwa terdapat $26,32 \%$ anak (5 orang) memiliki peringkat cukup baik, 42,11 \% anak (8 orang) memiliki peringkat baik, dan 31,57 \% anak (6 orang) memiliki predikat sangat baik dalam menguasai matematika. Secara keseluruhan, nilai rata-rata dari kegiatan evaluasi pertama ialah 68,36 (cukup baik) dan meningkat menjadi 74,36 (baik) pada evaluasi kedua. Meningkatkan nilai rata-rata dari evaluasi tahap satu ke tahap dua tidak terlepas dari perlakuan yang diberikan selama kegiatan pendampingan.

Meningkatnya nilai rata-rata yang dicapai anak-anak berdasarkan hasil evaluasi mengindikasikan bahwa minat dan semangat mereka masih tetap terjaga walaupun mereka sudah lama tidak belajar secara luring di sekolah. Hal ini juga menunjukkan bahwa penggunaan Garasi kids yang terdiri dari modul dan video pembelajaran cukup membantu 
anak-anak untuk menguasai materi pelajaran. Hal ini senada dengan hasil penelitian yang mengemukakan bahwa penggunaan media pembelajaran dapat meningkatkan motivasi dan hasil belajar peserta didik (Audie, 2019; Mureiningsih, 2014). Selain itu, kondisi belajar yang hanya terbatas (beberapa orang per kelompok) membuat mereka menjadi lebih fokus sehingga lebih mudah menerima ilmu-ilmu baru yang diajarkan. Studi sebelumnya menyatakan bahwa terbatasnya peserta didik dalam kegiatan belajar dan dipadu dengan penerapan metode belajar tertentu dapat meningkatkan konsentrasi peserta didik sehingga mereka lebih mudah menerima materi (Manurung \& Simatupang, 2019). Dengan demikian, kehadiran Garasi kids di Rumah Belajar Garasi cukup memberikan manfaat positif untuk menjaga semangat belajar anak-anak yang terbukti dari adanya peningkatan nilai evaluasi dan antusiasme mereka dalam mengikuti program kegiatan yang diselenggarakan Rumah Belajar Garasi bersama tim pengabdian.

Tabel 4. Nilai dan predikat dari hasil evalusi pertama dan kedua

\begin{tabular}{|c|c|c|c|c|}
\hline Kelompok & Kelas & Nama Sapaan & Nilai Evaluasi 1 & Nilai evaluasi 2 \\
\hline \multirow[t]{6}{*}{1} & II SD & 1. Putra & $55(\mathrm{~K})$ & $61(\mathrm{CB})$ \\
\hline & & 2. Amel & 70 (CB) & 76 (B) \\
\hline & & 3. Jelda & 70 (CB) & 75 (B) \\
\hline & & 4. Azam & 75 (B) & $80(\mathrm{SB})$ \\
\hline & & 5. Afi & 74 (B) & 78 (B) \\
\hline & & 6. Mila & 69 (CB) & 72 (B) \\
\hline \multirow[t]{4}{*}{2} & III SD & 1. Ami & 76 (B) & 80 (SB) \\
\hline & & 2. Cantika & $71(B)$ & $78(\mathrm{~B})$ \\
\hline & & 3. Bilqis & 77 (B) & $82(\mathrm{SB})$ \\
\hline & & 4. Nizam & $65(\mathrm{CB})$ & 72 (B) \\
\hline \multirow[t]{9}{*}{3} & IV SD & 1. Langit & $56(\mathrm{~K})$ & $62(\mathrm{CB})$ \\
\hline & dan V & 2. $\mathrm{Fa}^{\prime} \mathrm{i}$ & $61(\mathrm{CB})$ & 72 (B) \\
\hline & SD & 3. Zahra & $59(\mathrm{~K})$ & 70 (CB) \\
\hline & & 4. Ica & 78 (B) & $80(\mathrm{SB})$ \\
\hline & & 5. Julian & 78 (B) & 85 (SB) \\
\hline & & 6. Dara & $60(\mathrm{~K})$ & 70 (CB) \\
\hline & & 7. Figi & $56(\mathrm{~K})$ & 65 (CB) \\
\hline & & 8. Dita & 72 (B) & 75 (B) \\
\hline & & 9. Namira & 77 (B) & $80(\mathrm{SB})$ \\
\hline Rata-rata & & & 68,36 (CB) & $74,36(B)$ \\
\hline
\end{tabular}

Tim pengabdian bersama pengelola Rumah Belajar Garasi juga mengadakan kegiatan tambahan yang tujuannya ialah untuk memacu kreativitas anak-anak. Kegiatan ini dikemas dalam bentuk kompetisi mewarnai dan membuat mozaik. Kegiatan tersebut dilaksanakan pada jadwal yang berbeda sebagai selingan agar anak-anak tidak bosan mengikuti pembelajaran bernalar matematika. Kegiatan dan hasil karya anak-anak ditunjukkan pada Gambar 5. kreativitas anak-anak dalam memadukan warna dan teknik melakukan pewarnaan dipotret dalam kegiatan mewarnai, sedangkan kreativitasnya untuk memadukan biji-bijian menjadi pola yang menarik dipotret dalam kegiatan membuat mozaik. Kegiatan mewarnai bersifat individu, sementara kegiatan membuat mozaik dilakukan secara berkelompok. Dengan cara ini anak-anak dapat dipantau kemampuan individunya dan kemaupuan berkelompoknya dalam berkreativitas. 


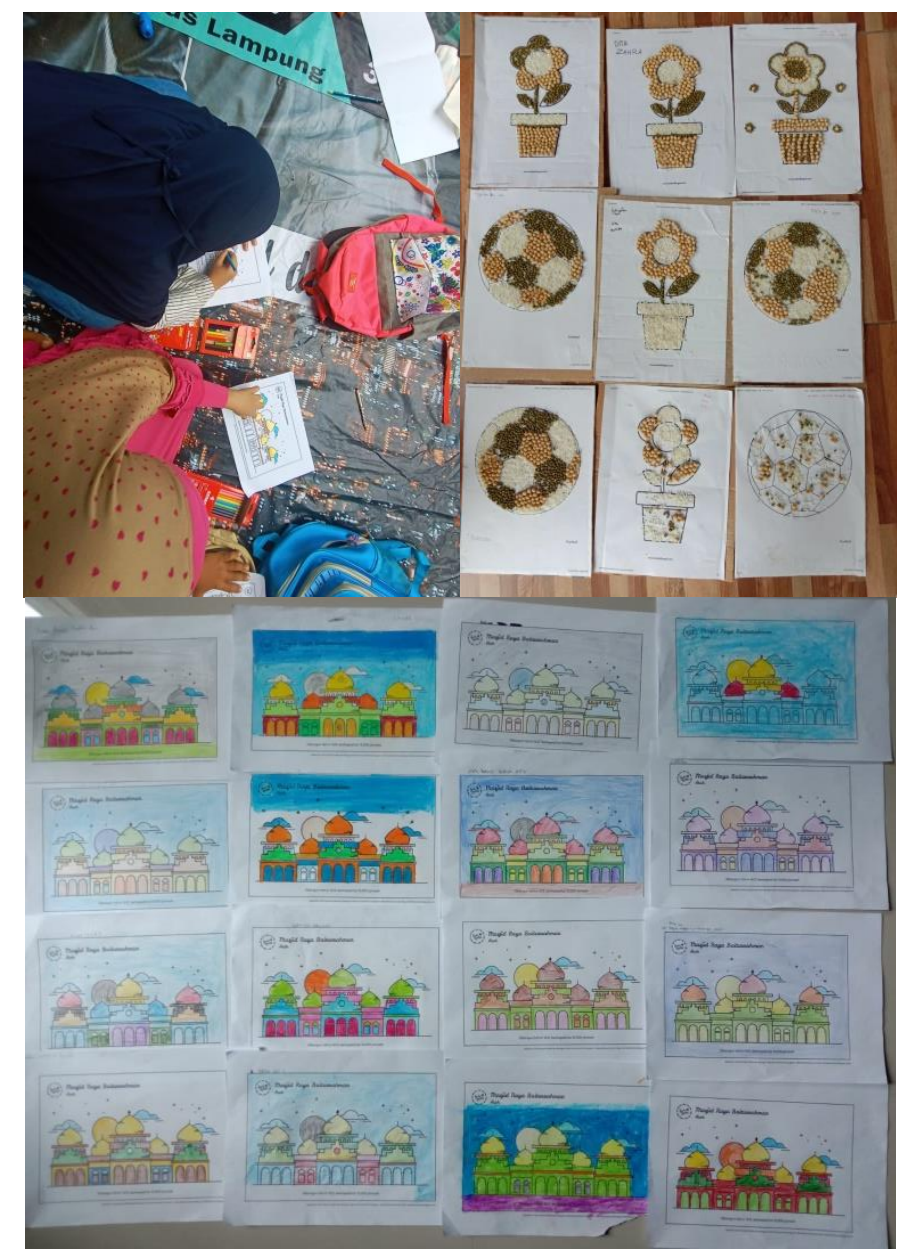

Gambar 5. Kreativitas anak-anak dan hasilnya

Dari kegiatan mewarnai diketahui terdapat beberapa anak yang nalar matematikanya pada predikat kurang, namun mereka memiliki kreativitas yang baik saat mewarnai sebuah gambar. Mereka mampu berimajinasi dan menuangkannya dengan teknik pewarnaan yang harmoni sehingga dihasilkan gambar yang indah. Pada kegiatan pembuatan mozaik, anakanak berusaha kerjasama untuk menuangkan idenya sehingga terdapat beberapa kelompok yang menghasilkan karya mozaik yang bagus. Mereka menyusun biji-bijian dengan paduan yang cocok sehingga dihasilkan pola yang menarik. Dari kegiatan ini, anak-anak yang menghasilkan karya terbaik diberi hadiah sebagai apresiasi untuk mereka. Karya yang telah dibuat oleh anak-anak ini dibagikan kepada orang tuanya melalui media sosial WhatsApp agar mereka mengetahui bakat dan kreativitas anaknya dengan harapan kelak mereka bisa mengarahkan pendidikan anaknya sesuai dengan minat dan bakatnya. Anak-anak sangat senang mengikuti kegiatan ini karena dapat bermain sambil belajar.

Selain program tambahan yang ditujukan untuk menumbuhkan kreativitas, Rumah Belajar Garasi beserta tim pengabdian menghadirkan program yang ditujukan untuk menumbuhkan minat baca anak-anak. Kami menghadirkan mobil pintar yang membawa koleksi buku-buku bacaan berkarakter. Anak-anak bergembira dengan hadirannya mobil pintar karena mereka dapat menikmati koleksi buku bacaan full color yang terdiri dari buku sains, cerita, buku agama, dll. Buku-buku karakter dan full color merangsang ketertarikan anak-anak 
untuk mengeksplorasinya karena paduan berbagai warna yang ada di dalam buku membangkitkan motivasi, perasaan, dan perhatian anak-anak (Purnama, 2010). Mereka sangat antusias membaca buku satu demi satu karena sangat menarik bagi mereka. Mereka juga mendapatkan game ringan dan motivasi dari crew mobil pintar agar mereka senang membaca buku seperti ditunjukkan pada Gambar 6 .

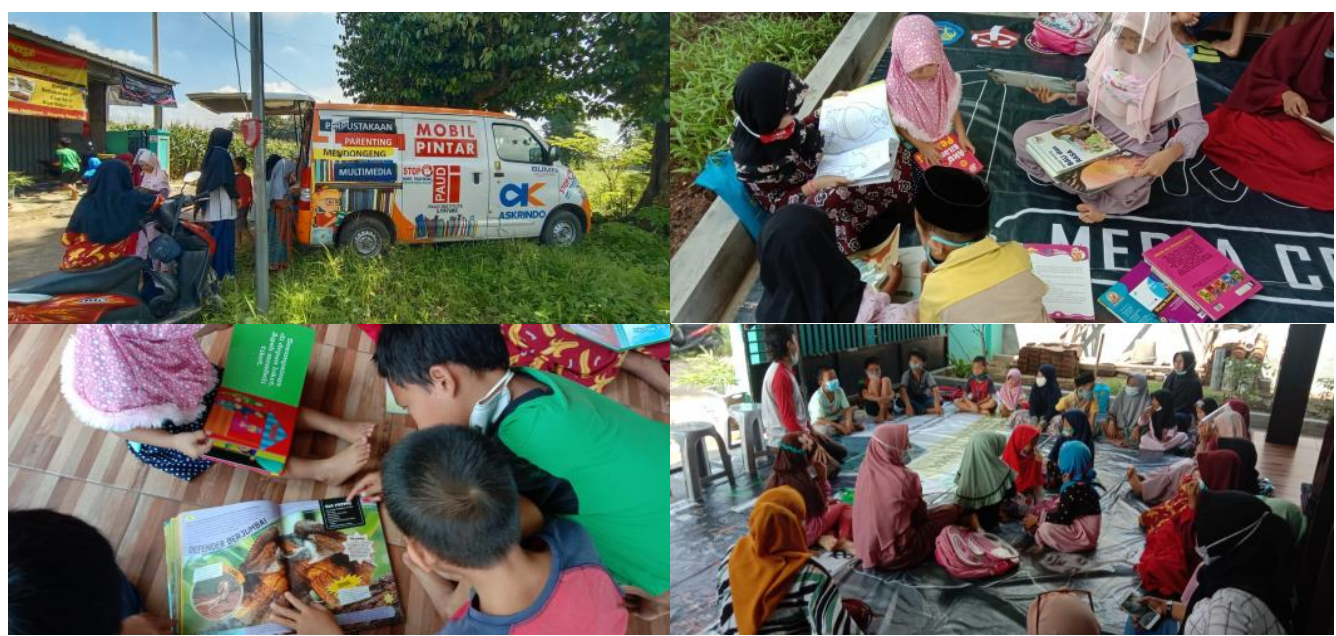

Gambar 6. Kunjungan mobil pintar dan pemberian motivasi oleh crew di Rumah Belajar Garasi

\section{Kesimpulan}

Penerapan Garasi kids sebagai media pembelajaran untuk menjaga semangat belajar anak-anak di sekitar Jalan Kramat Jaya RT 04 Hajimena di kala pandemi Covid-19 tercapai dengan baik. Penggunaan media ini mendorong tumbuhnya kemampuan mereka dalam bernalar matematika. Meskipun, terdapat sebagian kecil anak-anak memiliki predikat cukup baik dalam menyerap materi, namun mereka memiliki sisi unggul dalam kreativitas seni dan kerja sama. Program tambahan yang dibuat juga mampu menumbuhkan minat baca anakanak.

\section{Ucapan Terima Kasih}

Penulis mengucapkan terima kasih kepada Lembaga Penelitian dan Pengabdian Pengabdian Kepada Masyarakat (LPPM) Universitas Lampung yang telah memberikan dukungan dana melalui hibah pengabdian pemula dengan nomor kontrak 1896/UN26.21/PM/2021.

\section{Referensi}

Anugrahana, A. (2020). Hambatan, Solusi dan Harapan: Pembelajaran Daring Selama Masa Pandemi Covid-19 Oleh Guru Sekolah Dasar. Scholaria: Jurnal Pendidikan Dan Kebudayaan, 10(3), 282-289. https://doi.org/10.24246/j.js.2020.v10.i3.p282-289

Audie, N. (2019). Peran Media Pembelajaran Meningkatkan Hasil Belajar Peserta Didik. In Prosiding Seminar Nasional Pendidikan FKIP (Vol. 2, pp. 586-595).

Cahyati, N., \& Kusumah, R. (2020). Peran Orang Tua Dalam Menerapkan Pembelajaran Di Rumah Saat Pandemi Covid 19. Jurnal Golden Age, 4(1), 4-6. 
https://doi.org/10.29408/goldenage.v4i01.2203

Handayani, T., Khasanah, H. N., Yosintha, R., Tidar, U., Artikel, H., Tegalarum, D., \& Tegalarum, D. (2020). Pendampingan Belajar di Rumah bagi Siswa Sekolah Dasar Terdampak Covid-19. Adipraja: Jurnal Pengabdian Kepada Masyarakat, 1(1), 107-115. http://dx.doi.org/10.31002/abdipraja.v1i1.3209

Hayati, N., Harianto, F., \& Harianto, F. (2017). Hubungan Penggunaan Media Pembelajaran Audio Visual dengan Minat Peserta Didik pada Pembelajaran Pendidikan Agama Islam di SMAN 1 Bangkinang Kota. Al-Hikmah, 14(2), 160-180. https://doi.org/10.25299/alhikmah:jaip.2017.vol14(2).1027

Jatmika, H. M. (2005). Pemanfaatan Media Visual dalam Menunjang Pembelajaran Pendidikan Jasmani di Sekolah Dasar. Jurnal Pendidikan Jasmani Indonesia, 3(1), 89-99. https://doi.org/10.21831/jpji.v3i1.6176

Lestari, I. P., Purnamasari, V., \& Purnamasari, I. (2021). Pendampingan Siswa pada Program Belajar Dari Rumah untuk Membangun Semangat Siswa Sekolah Dasar di Desa Pekalongan Kecamatan Winong Kabupaten Pati. Jurnal Inovasi Pembelajaran Di Sekolah, 2(1), 12-17. https://doi.org/10.51874/jips.v2i1.10

Manurung, M. P., \& Simatupang, D. (2019). Meningkatkan Konsentrasi Anak Usia 5-6 Tahun Melalui Penggunaan Metode Bercerita di TK ST Theresia Binjai. Jurnal Usia Dini, 5(1), 58-75. https://doi.org/10.24114/jud.v5i1.16189

Mureiningsih, E. S. (2014). Meningkatkan Hasil Belajar Siswa Melalui Media Pembelajaran Multimedia Interaktif. Jurnal Madaniyah, 7, 214-229.

Mustara, \& Santaria, R. (2020). Dampak Pandemi Covid-19 terhadap Proses Pengajaran bagi Guru dan Siswa. Jurnal Studi Guru Dan Pembelajaran, 3(2), 289-295. https://doi.org/10.30605/jsgp.3.2.2020.293

Purnama, S. (2010). Elemen Warna Dalam Pengembangan Multimedia Pembelajaran Agama Islam. Al-Bidayah: Jurnal Pendidikan Dasar Islam, 2(1), 113-130. https://doi.org/10.14421/albidayah.v2i1.102

Rosidah, A. (2016). Penerapan Media Pembelajaran Visual untuk Meningkatkan Pemahaman Konsep Siswa Pada Mata Pelajaran IPS.. Jurnal Cakrawala Pendas, 2(2), 121-126.

Sari, R. P., Tusyantari, N. B., \& Suswandari, M. (2021). Dampak Pembelajaran Daring Bagi Siswa Sekolah Dasar Selama Covid-19. Prima Magistra: Jurnal Ilmiah Kependidikan, 2(1), 9-15. ttps://doi.org/10.37478/jpm.v2i1.732

Siregar, N. R. (2017). Persepsi Siswa Pada Pelajaran Matematika: Studi Pendahuluan Pada Siswa Yang Menyenangi Game. In Prosiding Temu IImiah X Ikatan Psikologi Perkembangan Indonesia (pp. 224-232).

Wardani, A., \& Ayriza, Y. (2021). Analisis Kendala Orang Tua dalam Mendampingi Anak Belajar di Rumah Pada Masa Pandemi Covid-19. Jurnal Obsesi : Jurnal Pendidikan Anak Usia Dini, 5(1), 772-782. DOI: 10.31004/obsesi.v5i1.705

Yuhenita, N. N., Muliyani, R., Alfahmi, R. A., \& Abdillah, M. Z. (2021). Pendampingan dalam menghadapi pembelajaran di masa pandemi bagi warga dusun macanan. Selaparang Jurnal Pengabdian Masyarakat Berkemajuan, 4(2), 215-219. https://doi.org/10.31764/jpmb.v4i2.3711 